\title{
Exploring connections: Reflections on mother-tongue education in postcolonial Uganda
}

\author{
Medadi E. Ssentanda \\ Department of General Linguistics, Stellenbosch University, South Africa \\ E-mail: ssentandam@yahoo.com.sg/medadies@gmail.com
}

\begin{abstract}
Mother-tongue (MT) education in Uganda, like in many other countries, is a highly contentious subject. A plethora of problems plague MT education and all are similar to those mentioned in more than six decades of research and evaluations on the topic from numerous countries across the world. Based on fieldwork conducted in four primary schools in the Rakai district of Uganda, this paper attempts to demystify and critically theorise practices and ideologies of language in education. This study is inflected by the theoretical work of Tollefson (1991), particularly his challenging remark that "language is built into the economic and social structure of society so deeply that its fundamental importance seems only natural. [...] For this reason, language policies are often seen as expressions of natural, common-sense assumptions about language in society" (Tollefson 1991:2). This paper therefore sets out to surpass the mere cataloguing of problems bedevilling MT education in Uganda by proposing an account of their possible genesis. Through an examination of dysfunctional state and government structures, the role of linguistic ideology as well as the distribution of symbolic and material wealth, it is herein argued that there should be a shift from the structural-functional model, where policies are considered bodies of discourse that should, or that fail to, be implemented. It is proposed rather that the education system mirrors a wider societal concern in which colonial legacies are miserably reproduced in postcolonial Ugandan structures.
\end{abstract}

Keywords: Mother-tongue education, transition, English, teacher attitudes, postcolonialism, Uganda

\section{Okwekaliriza Obukwatane: Okwefumiitiriza ku Kusomesereza mu nnimi enzaaliranwa mu Uganda eyeefuga}

Okufaananako ne mu nsi endala, ensonga y'okusomesereza mu nnimi ennansi mu Uganda ewakanirwako. Ebizibu nkumu ebifumbekedde mu kusomesereza mu nnimi ennansi era nga bifaanaganira ddala n'ebyo abanoonyereza bye bazzenga banokolayo ku nsonga eno mu nsi ez'enjawulo mu nsi yonna. Ebyogerwako wano byesigamiziddwa ku kunoonyereza okwakolebwa mu masomero ga nnakasooka ana (4) mu distrikiti y'e Rakai mu Uganda. Olupapula luno lugezaako okwekkaanya n'okwekaliriza, mu ngeri ekolokota, endowooza n'ebikolebwa mu kusomesereza mu nnimi ennansi. Nga nsinziira ku ndowooza ya James Tollefson (1992:2) naddala ku kirowoozo kye ekisoomooza nti "olulimi luzimbirwa ku ntereeza 
y'ebyenfuna mu kitundu era nga lwesoggera ddala wala kutuuka ku kuba nti omugaso gw'olulimi omukulu gulabibwa nga ekijjanabutonde. N'olw'ensonga eyo, enkola z'eby'ennimi zitera okulabibwa ng'ebintu bye tutwala nti bijjanabutonde era ebikolebwa n'amagezi amazaale ku nsonga z'okusalawo ku lulimi mu kitundu." Awo nno olupapula luno lugezaako okusukka ku kunokola obunokozi ebizibu ebiri mu kusomesereza mu nnimi ennansi mu Uganda. Bwe kityo nno olupapula luno lwoleka ensibuko y'ebizibu bino. Nga twekaliriza entereeza ya gavumenti erabika okuba nga tetambula bulungi wamu n'endowooza eyeesigamiziddwa ku lulimi n'engeri y'okutuuka ku ngabana y'ebyo ebirabibwako eby'obugagga, kiwakanwako wano nti wasaana okubaawo okwebembula ku kutunuulira obutunuulizi enkola z'eby'ennimi ng'ekintu ekirina okwogerwako, ekirina okutuukirizibwa oba ekirina okulema okutuukirizibwa. Wabula, kiteesebwa wano nti omuyungiro gw'eby'enjigiriza ebeera ndabirwamu ya kitundu omweyolekera, mu ngeri ey'ennaku, ebisigalira by'obufuzi bw'amatwale mu ntereeza ya gavumenti ya Uganda eyeefuga.

Ebigambo ebikulu: Okusomera mu nnimi enzaaliranwa, okuseetuka, Olungereza, entwala z'abasomesa, obusukkameefuga, Uganda

\section{Introduction}

More than six decades of research into the failure of the implementation of mother-tongue (MT) education programmes in various countries has yielded interesting cataloguing of problems associated with the execution of such programmes. Acknowledging that Uganda has been an independent country since 1962, this study considers why, more than fifty years down the line, MT education continues not to function effectively as expected. Numerous studies have highlighted the need for MTs in the classroom in addition to their important role in learning and acquiring both content and a second language (e.g. Association for the Development of Education in Africa (ADEA) 2005; Cummins 1980, 1981, 2000; Fafunwa, Macauley and Sokoya 1989; Skutnabb-Kangas 2011).

Even though MT education is noted to have the benefits mentioned above, it has also been noted that its implementation is affected by various factors. Several studies (e.g. Wang 2008; Spillane, Reiser and Reimer 2002; Dutcher 2003; Stroud 2002; Fafunwa et al. 1989; Akinnaso 1993; Tse, Shum, Ki and Wong 2001; Tembe and Norton 2008; Obanya 1999) have underlined the need for appropriate teacher education, the importance of community involvement in curriculum and language policy formulation, the need for the provision of sufficient study materials, as well as the imperative need to educate the community about the benefits of MT education. All these issues need to be addressed in order to for MT education to be implemented. This paper attempts to divert from a further cataloguing of identical problems and recommendations by delving into possible explanations for the cause of these challenges.

This paper stems from a larger $\mathrm{PhD}$ project which explores how teachers understand and manage the process of transitioning from MT to English in Uganda. Using data gathered in fieldwork conducted in four primary schools in the Rakai district in (rural) Uganda, the present analysis sets out to demystify and critically theorise practices and ideologies of language in education in post-independence Uganda. The main premise of this paper is that current MT education systems mirror wider societal concerns regarding the manner in which colonial legacies are reproduced in postcolonial Ugandan educational structures. The paper will 
therefore offer a synoptic consideration of problems, failures and recommendations of previous studies and evaluations in the Ugandan context. Thereafter, a close reading and theorisation of the origin of these problems will be offered.

\section{Synoptic overview of failure of mother-tongue education in postcolonial Uganda}

As has been the case in many postcolonial African countries, the unsatisfactory levels of educational achievement motivated Uganda in 2006/2007 to modify subject-based curricula in favour of MT-instructed thematic curricula for Primary (P)1 to P3. P4 was identified as a transitional year in which there was minimal use of MTs as learners were prepared to transition to English which was the language of learning and teaching (LoLT) from P5 through to P7. Urban schools, presumed to have complex multilingualism, use English as an LoLT throughout the primary cycle and teach the MT as a subject (Government of Uganda, 1992, Kajubi 1989, Kateeba 2009, National Curriculum Development Centre (NCDC) 2011). Disparaging criticism has been levelled against this early-exit model which limits MT instruction to only the first three or four years of education due to its ultimate aim of monolingualism and the promotion of foreign languages (Ball 2011, Stroud 2002).

Previous studies on Uganda have catalogued problems associated with the implementation of MT education and teacher attitudes towards MT education. MT education has hitherto been limited and affected by communities' preferences for English and/or other dominant languages in Uganda other than children's MTs. This is because upward social mobility and access to employment is not directly related to the consummate mastery of MTs (Tembe and Norton 2008). Furthermore, it has been highlighted that teachers lack appropriate training which would equip them with the necessary skills to handle MT teaching. For instance, upon the reintroduction of MT teaching in 2006/2007, teacher training was completed in two weeks (Altinyelken 2010). In addition, MTs are not furnished with enough materials as is the case with English and other, more dominant languages (Tembe and Norton 2008). Furthermore, MT education in Uganda has been reported to be affected by large learner-to-teacher ratios (Kisembo 2008). All these challenges have increasingly impeded the implementation of MT education in Uganda.

\section{Methodology}

The study which informs the current paper involved collecting data from 10 primary schools during the months of September to November 2012. However, for the purposes of this paper, data from four rural (Rakai district) schools is considered. A mixed-methods methodology employing questionnaires, interviews and classroom observations was employed because such studies provide a broad overview of a representative sample of a large population (Mouton 2001). Mixed-method approaches to research also have the potential of enriching as well as cross-validating research findings (Gillham 2007). This approach was chosen because (i) data from surveys allow for generalisations of sample statistics to estimate population parameters within calculable margins of error; and (ii) the methods used within this approach (e.g. questionnaires) elicit reliable answers to questions on a wide variety of topics and are also more representative than studying individuals (Gillham 2007, Marsden and Wright 2010). Mixedmethod research also helps in addressing both the "what" (numerical and qualitative data) and the "how or why" (qualitative) types of research questions. 
Since questionnaires are rarely sufficient as a method on their own (given their remoteness from the reality of people's lives), follow-up interviews were conducted with a small number of those who answered the questionnaires (Gillham 2007). Classroom observations also took place so that what teachers reported in questionnaires could be validated through the observation of actual classroom activities. The data presented in this paper are largely drawn from the interviews conducted for this study, in order to support the arguments put forward.

\section{Causes of failure of implementation of mother-tongue education in postcolonial Uganda}

\subsection{Dysfunctional educational structures}

An exploration of the nature of language-in-education policies formulated in post-independence Uganda can help us to understand the root causes of MT failure in Uganda. For instance, by closely looking at Lasebikan, Ismagilova and Hurel (1964), the Unesco Regional Office for Education in Africa report (1985), the Government White Paper on Education (Government of Uganda 1992), Ssekamwa (2000), National Curriculum Development Centre (2006a, 2006b, 2006c, 2011) and Kateeba (2009), one notes that language-in-education policies have been formulated with "escape clauses" that make it easy for the government and/or schools not to take responsibility for MT implementation.

Although it is not fully reported in the literature how all these efforts towards the development and employment of MTs in Uganda's education system have kept fluctuating, Bamgbose (1989) provides a clue to what might have happened to the employment of African languages in education in the 1960s. Bamgbose reports that, soon after the attainment of independence, there was a movement towards the learning of and in foreign languages because of the inherent abundance of opportunities these languages promised, such as serving in government. This wave may have eliminated and slowed down the use of MTs in Uganda's primary education. Between the 1960s and 2006/2007, the use of MTs in Uganda's primary education was not formalised. In most cases it was haphazardly practiced in rural schools. The limiting of MT teaching and use of MTs as the LoLT for the first three or four years of primary schooling were observed to be dysfunctional and hence may be called an institutional policy disjuncture because of the inherent promotion of English. As MTs are seen not to play qualification roles required in, for instance, accessing government jobs and participating in politics (Tollefson 1991), educators find it safe to eliminate them or teach them when it is convenient. This is why the use and teaching of these languages are limited to only the first three or four years of primary schooling.

As previously mentioned, over the years in Uganda, MT-education policies have been drafted with escape clauses. Firstly, the selection of an LoLT is left in the hands of either schools or district authorities. Schools have used such clauses (or opportunities) to pronounce themselves as too multilingual, thus constructing a problem of complex multilingualism that does not favour MT education. This is supported by the current study which found precisely this problem in private schools in the rural Rakai district. Surprisingly, the same schools teach MTs as a subject. A natural question to ask here would be how these schools arrive at a dominant MT to teach as a subject. It should also be borne in mind that the language-in-education policy encourages urban schools to teach MTs as subjects, but to use English as the LoLT. The escape clause in the current policy allows schools to teach in English when it is difficult to determine 
a dominant language in the community in which the school is situated. Consequently, private schools have used escape clauses as opportune routes to start the teaching and use of English as the LoLT earlier in children's education than what is prescribed in Uganda's current MT policy. It is the same case with government schools.

Secondly, all previous language-in-education policies have been lax on the examination of MTs in education. Lasebikan et al. (1964) noted that it was awkward that the learners' languages, which were used as the LoLT for the first few years of schooling, were not compulsory subjects for the primary leaving certificate. In terms of MT examination, the current policy is no different as it states that MTs may or may not be examined at the end of primary schooling (Government of Uganda 1992). Such a provision is an escape route allowing teachers or schools to disregard the teaching of MTs in schools. The following extracts from the teachers' narrations demonstrate how schools "escape" policy implementation. In these extracts, teacher turns are marked with $\mathrm{T}$ and L(s) stands for learner(s). The Luganda text is in bold, the translation is in italics and the English borrowings within the Luganda utterances are in normal typeface.

Extract 1: Interview with a P5 teacher in School B (government school)

1T: Mhm. Engeri gye tubeera nti tuli batonotono, nga bw'olabye abasomesa, twettanira nnyo bino ebigenda okubuuzibwa, bye tusinga okuteekako amaanyi. Kale weesanga nga babiwadde n'erinnya nti major subjects, zino minor subjects.

Yes. Since we are quite few just as you have observed the number of teachers, we tend to concentrate on what is to be examined; that is where our energies are rested. You find that subjects are given names such as major and minor subjects.

${ }_{2} \mathrm{MS}: \quad$ Mhm.

Yes

3T: $\quad$ Kati omwana ng'ali bubi nnyo mu kubala, kizibu nnyo okugamba nti oli ave mu kumusomesa okubala ate adde mu Luganda.

If a child is badly off in mathematics, it is very difficult for one to leave mathematics and instead teach Luganda.

${ }_{4} \mathrm{MS}$ : Mhm.

Yes

${ }_{5} \mathrm{~T}$ : Nga tetulabayo abimubuuza. Kye kimu ku binafuya abantu okusomesa Oluganda.

And yet we do not anticipate anybody to examine him/her in that. That is one of the reasons that demotivate the teaching of Luganda as a subject.

In turn 1, the respondent argued that since there were few teachers at the school, they concentrated on examinable subjects and disregarded the unexaminable ones like MT. In turn 3 , the teacher reasoned that if a learner was performing poorly in mathematics, for instance, it was illogical for them to concentrate on teaching this learner the MT and not mathematics. In line 4, the teacher said that they could not concentrate on teaching Luganda as a subject when, actually, there was nobody to examine the learners in the language. In fact, teachers reported that learners did not even sit end-of-term or end-of-year examinations in MT as a subject. In 
the following extract, teachers from School A (government school) confirmed that MT as a subject was given minimal attention.

Extract 2: Interview with P5 teachers in School A (government school)

1MS: Kati mu P4 ne mu P5 Oluganda musigala mukyalusomesa?

Do you then continue teaching Luganda in P4 and P5?

1T1: Yee, kyandibadde nti wonna ppaka kumalako seven... Yes, it would be the case that it is taught all through [P] seven...

3T2: Nga subject. As a subject.

4T1: Nga subject, naye lwakuba nti olumu munnange nga bw'omanyi n'abantu obudde...

As a subject, but my friend, as you know some people with time...

${ }_{5} \mathrm{~T} 2: \quad$ Ate nga n'engeri gy'etali examinable ...

And also being an unexaminable subject...

6T1: Kati ekyo kiwa abantu obunafu.

${ }_{7} \mathrm{MS}$ : Eeh.

With that people become lazy.

I see.

8T1: Ne banafuwa. Abantu awo bajjamu obunafu n'agamba eeh...

They become lazy; at that point people become lazy saying...

${ }_{9} \mathrm{MS}$ : N'agamba nti lwaki obudde tubumalira wano ng'ate science ye wookubuuzibwa?

They ask a question, why do we waste time with this yet it is science that will be examinable?

10T1: Ahaa. Kuba ky'ova olaba nti bw'ogenda mu gundi, twesiba ku major. Zino eziri major ze tukola ki?

Yes. That's why you find that when you go to this..., we only concentrate on majors. The major ones are what we do what?

In line 1, the teacher was asked whether the MT continued to be taught as a school subject after P3. When the teacher replied in line 2, he demonstrated that he was aware that the subject was supposed to be taught right through to P7, but the excuse teachers use is that of time (see turn 4). In addition, the issue of examinations (see turns 4 and 5) makes teachers "lazy" (see turn 6), and they therefore disregard the teaching of this subject. In line 11, the teacher explained that since MT as a subject was not examinable, they only concentrated on examinable subjects such as Science and Social Studies (see turn 10). In other words, the time allocated for teaching the MT was used to teach other examinable curriculum areas.

As previously mentioned, there is a huge gap between teacher training and language-ineducation needs in Ugandan primary schools, which serves as an indicator of dysfunctional educational structures. The education system is not well-packaged to facilitate and support the training needs in primary schools. In primary teacher training colleges (PTTCs), there are no local languages taught to prepare teachers for MT teaching in schools. At the time that MT education was introduced (2006/2007), there were only nine languages that had approved orthographies and were therefore listed as LoLTs. By 2009, Kateeba (2009) reports that 26 more had come on board. This brings the number to 35 languages listed as LoLTs by NCDC. 
However, when the local languages taught in secondary schools (which produce candidates for PTTCs) are compared, there are only six examinable subjects at senior four (UNEB 2012). This means that the remainder of the languages are taught by unqualified people. Such an arrangement is symptomatic of a dysfunctional education structure.

Since the educational structures are dysfunctional, the promises made in policy guidelines are marginally fulfilled. For example, NCDC promises that all teaching and learning materials will be provided in languages familiar to the learners (2006c). However, this study's findings reveal that the reading and teaching materials in MTs were inadequate and, in some cases, nonexistent. Moreover, the available materials seem to have been hurriedly written by under- or unqualified people as they contain a lot of misleading information (e.g. in NCDC 2006b). This may also be symptomatic of dysfunctional educational structures as it is possible that little effort was made to recruit qualified professionals to draft local language curriculum materials because these languages are considered less important compared to English. In fact, the largest portion of the curriculum to be instructed through MTs is in English. Teachers in this study have reported that the MT curriculum was basic and was not sufficiently supported with reference books. This is illustrated in Extract 3, where a teacher struggles to teach learners in the MT of Luganda without any reference books, and in Extract 4, where one of the teacher interviewees mentioned that teachers rely on "creativity" to find solutions to the challenges they face regarding teaching and learning materials (see Extract 4).

In the classroom observation of a P3 class in School C (see Extract 3), there was a moment when a teacher wanted to illustrate something to the learners. The illustration required learners to possess one of the old Luganda books, Kisumuluzo, that is used to teach reading. The teacher mentioned that if the learners had this book, he would show them what he was illustrating and/or explaining during the lesson (see line 1). From this extract, it is evident that the teacher believed that the learners had refused to buy this book (see line 3).

Extract 3: Classroom observation of a P3 class in School C (private school)

1T: Tusobola okuba n'ekigambo, 'mpya'. 'Mpya', uhm? 'Mpya', ky'ova olaba singa obadde olina Kisumuluzo yo, obadde ojja kubikkula we nandikugambye okubikkula, osangemu ebigambo bino nga weebiri bino. Enkuba ekya amangu si mbi. Olulimi ndwogera. Enkwenge, enswiriri. Ebigambo ebyo mubiwulira?

We can have a word "mpya". "Mpya", yes? This is why if you had Kisumuluzo you would open where I would direct you and then you would find these words there: "Enkuba ekya amangu si mbi"; "Olulimi ndwogera"; "enkwenge"; "enswiriri". Have you listened to those words?

${ }_{2}$ Ls: Yee.

Yes.

3T: Mu kisumuluzo wo Kisumuluzo yakulema okugula. (...) You failed to buy Kisumuluzo (...)

The following extract (Extract 4) illustrates one teacher's concern with regard to lack of reference materials in the $\mathrm{P} 2$ classroom, and this teacher's subsequent creativity. 
Extract 4: Interview with a P2 teacher in School C (private school)

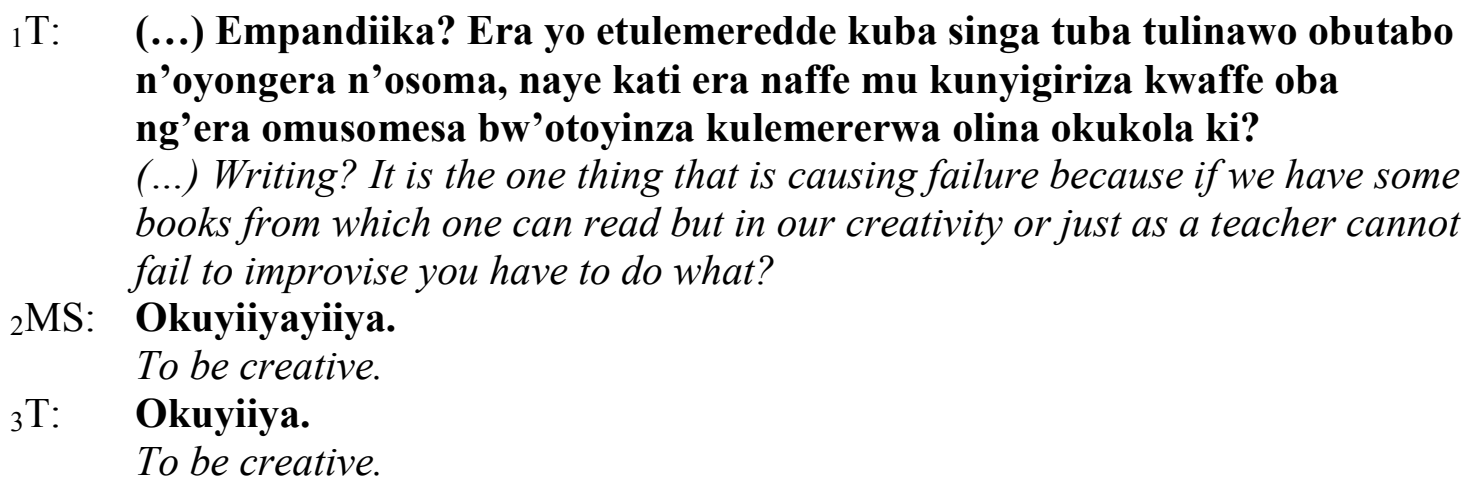

Speaking on behalf of teachers in general, the teacher in Extract 4 notes that the students experience challenges with regard to Lugandan orthography because of the lack of reference materials with which they can work. This teacher believes that this dearth was preventing the students from mastering Lugandan orthography. However, the teacher said that they continue to improvise and be creative (lines 1 and 3 ) in an attempt to overcome this challenge. The fact that learning an MT through this MT is enforced cannot be overemphasised.

As part of the response to the dysfunctional education structures, some schools - particularly private schools - have resisted the thematic curriculum in preference for the subject-based curriculum that was in place before 2006/2007. There is thus a clear division in the teaching and learning process(es) between learners who attend government schools, where the teaching of a thematic curriculum takes place in the MT, and learners who attend private schools, especially in terms of exposure to different content. The consequences of this practice render the learners at a serious disadvantage.

Read and Enyutu (2005) cautioned the Ugandan Ministry of Education and Sports (MoES) in their report that investigated educational quality, language use and reasons for low achievement. The authors (2004:5) state that

[...] reform of the primary curriculum [...] will be insufficient to achieve high levels of basic literacy and numeracy by the end of seven years of primary education. Urgent but closely integrated reforms are also proposed in local language policy, learning materials provision and use, pre-service and in-service teacher training, primary school supervision and mentoring and in assessment

Perhaps, because of the nature of colonial educational structures, these recommendations were not afforded sufficient attention.

In sum, the educational structures in Uganda can be seen as dysfunctional on two counts:

(i) the failure to formulate strong MT programmes that promote local languages in Uganda: the formulated policies limit MTs to only the first three or four years after which it is English only, just as in the colonial era (Stroud 2002); and

(ii) the failure to put in place efficient government structures to monitor and/or supervise the implementation of language-in-education policies in schools (Read and Enyutu 2005). 


\subsection{Language, power and colonial legacy}

It is important to note that the attitudes of teachers, parents, language policy-makers and the general public towards their MTs, in Africa in general and more specifically in Uganda, are a result of the inherited linguistic, power and colonial legacies. Colonial education was structured so as to produce people who could assist in accomplishing colonial work. To qualify for these jobs, one had to be proficient in languages such as English, French, German and Portuguese. Getting a job with a colonial office was prestigious and it elevated many in terms of social strata. Consequently, it was believed that proficiency in one of the aforementioned languages led to success in life. In some instances, Africans were regarded as educated if they "denied" their culture, of which language is an inevitable part. Stroud (2002) offers a fascinating analysis of this colonial dynamic in his study of assimalados in Mozambique.

In Uganda, English is the official language in all formal domains, as well as being the examination language at all levels of education. This stipulation comes with overt actions and practices. For instance, language-in-education policies have been drafted in such a way that English is introduced as early as possible due to the belief that the earlier one starts to learn a second language the more proficient one becomes (Benson 2008). Teachers' attitudes towards the teaching and learning of MTs are influenced by this belief and conception as seen in the following extracts:

Extract 5: Interview with a P1 teacher in School B (government school)

1MS: How do you feel about the fact that the children you teach learn through MT but you were taught through English?

2T: Bambi nfuna okunyolwa.

Oh no, I get so sad.

${ }_{3} \mathrm{MS}$ Mhm.

Yes

4T: Nga ndaba nga nze ndaba eyamala essaawa ezisinga zonna nga ndi mu Luzungu, nga nange olumu luntawaanya, kyokka ate nga ye afuna eddakiika aga, asatu emyaka gye esatu egyo.

Seeing that I spent more hours in [learning through] English and yet I sometimes experience challenges with it, and yet this learner gets only thirty minutes [each day] for those three years.

${ }_{5} \mathrm{~T}$ Kyokka nga bw'anaatuuka mu gwokuna ogw'okujoininga atandike okuba nga..., ahaa! Mu butuufu emyaka gye omusanvu giggwaako aba akyayagala ayongereyo emyaka emirala gye yasooka okwonoona wansi eno. And yet when s/he gets to the fourth year where s/he starts... haa! The truth is the seven years will go when this child will need more years, possibly the number of years that s/he wasted first.

Extract 6: Interview with a P3 teacher in School B (government school)

1MS: Naye okiwulira otya okuba nti ggwe kati b'osomesa obasomeseza mu Luganda?

But then how do you feel about teaching your learners in Luganda? 
2T: $\quad$ Nze nkiwulira si bulungi.

I do not feel good about it.

${ }_{3}$ MS: Mhm.

Yes.

4T: $\quad$ Nkiwulira bubi.

Ifeel bad.

5MS: Lwaki?

Why?

6T: Nze ku lwange ynamba nti abayizi bano okuva wansi eno nga basoma

Luganda lwokka, kijja kubatwalira obudde buwanvu, okusobola okuyita Oluzungu. Gino emyaka gino esatu egya wansi, giringa egibafudde. Ate nga n'okuva mu P4 era nakyo kintu kimpi, kiba tekibamala okusinziira ku nsoma yaabwe.

I think that since these learners have started learning through Luganda, it will take them a long time to pass English. These three initial years are almost wasted. And yet from P4 [up to P7] is also a short time; it is not enough time for them judging from their way of learning.

Extract 5 was taken from an interview with a P1 female teacher at School B while Extract 6 was taken from the same school but with a P3 female teacher. The two teachers clearly point out that they felt bad that their learners had to learn in their MTs. Furthermore, these teachers believed that it was very difficult for learners to learn English when it was not used as an LoLT. The teacher in Extract 5 elaborated by drawing from her personal experiences, in that she learnt through English but still experienced problems in the language. She therefore felt that it may be problematic for those learners who would only begin to learn in English in their fourth year of schooling, as they would most likely need more than three years to learn English after it had been introduced as an LoLT. Interestingly, both teachers referred to the first three years of using MT as an LoLT as "wasted years" (Extract 6, line 6).

Sprenger-Tasch (2003:362) explains that this preference for English emanates from the colonial history which characterised English as a language of prestige, "the so-called chances [...] of upward mobility, often in the absence of an alternative it offers and sometimes lack of an alternative"(2003:362) (see also Kembo 2000). As parents hold similar views to those of the teachers, in addition to believing that their children will be more successful within society if they are proficient in English, many of them have elected to move their children from government schools (with MTs as the LoLTs) to private schools (with English as the LoLT from pre-primary). However, the idea that society "rewards" English proficiency is not necessarily the only factor contributing to this shift from government to private schools. An additional factor may be that parents view MT education as unrewarding. This is supported by the case of school fees being waivered for up to four children per family in government schools in Uganda. In 1997, this policy (entitled the Universal Primary Education policy) was introduced in Uganda resulting in the government choosing to allow four children in every family to study free of charge in government schools. However, in spite of this, parents still chose to enrol their children in private schools where they would have to pay for their children's education (see Table 1). Although there could be other factors contributing to the parents' decisions in these cases, on the basis of the teachers' reports in this study, it is most likely a result of the desire for their children to learn English as early and as fast as possible. 
Table 1. A comparison of number of learners in government and private schools

\begin{tabular}{|c|c|c|c|c|}
\hline Classes & $\begin{array}{c}\text { School A } \\
\text { (government) }\end{array}$ & $\begin{array}{c}\text { School B } \\
\text { (government) }\end{array}$ & $\begin{array}{c}\text { School C } \\
\text { (private) }\end{array}$ & $\begin{array}{c}\text { School D } \\
\text { (private) }\end{array}$ \\
\hline P1 & 24 & 34 & 90 & 47 \\
\hline P2 & 14 & 36 & 87 & 65 \\
\hline P3 & 17 & 44 & 104 & 84 \\
\hline P4 & 6 & 35 & 92 & 71 \\
\hline P5 & 10 & 27 & 75 & 70 \\
\hline
\end{tabular}

It should also be borne in mind that at present, pre-primary schooling in Uganda is not compulsory. This has, in some sense, created a hierarchy in rural schools in which private schools are seen as more prestigious because they have pre-primary sections; consequently, government schools fall short because learners who join their P1s have not attended preprimary. This too is an institutional policy disjuncture that leaves MT teaching disjointed.

The fact that there are two forms of instruction - government schools' use of MT teaching and private schools' use of English - has created unnecessary competition as to who produces more proficient English speakers in the eyes of the public. Government schools have already been affected in terms of their number of learners (see Table 1). In fact, at School A, there were no learners in the P7 class as they had all left in the endeavour of looking for "better" schools at which they could pass their primary leaving examinations.

There are, however, some areas in Uganda where MT education appears to be faring well. For instance, the northern part of Uganda - which is served by Mango Tree assisting in the Lango Literacy Project - has more learners in government schools than is the case in the Rakai district. This area appears to be more successful because there are a number of non-governmental organisations (NGOs) that have invested in MT education in this area and seem to have made MT education more acceptable (e.g. Mango Tree and the Lango Literacy Project, Save the Children, Unicef and Literacy and Adult Basic Education). The acceptance of MT education in this area could be further supported by the fact that this area had been war-torn for over 20 years and perhaps, for this reason, communities viewed education as an aid.

Therefore, the colonial legacy of the perception of English as the language of affluence and status is still very strong in the minds of the Ugandan public and has had practical ramifications. Although it is difficult to doubt the place of English since it is considered an international language, it is important to bear in mind that English can still be learnt without using it as an LoLT or introducing it as early as most teachers suggest.

\subsection{Social distribution of symbolic and material wealth}

It could be argued that the current language-in-education polices are drafted as they are because they have hidden agendas intended to restrict access to schooling (Shohamy 2006). This could be because those in power wish to retain their authority and keep the system as intact as possible. Tollefson theorises that "education is closely associated with economic class" (1991:8). As such, English is considered a "tool" and skill for wealth creation, education and employment (Tollefson 1991). 
Furthermore, Tollefson has observed that language defines identity and character as it has an impact on "family, friends, occupation, home and income" (1991:2,11). In other words, should one not speak the "right" language, one may also not have the "right" friends, skills and tools to lead him/her to the "right" occupations. Therefore, the "education process is so effective that most people are unaware of how language has affected their lives. Indeed, language is built into the economic and social structure of society so deeply that its fundamental importance seems only natural. For this reason, language policies are often seen as expressions of natural, common-sense assumptions about language in society" (Tollefson 1991:2). This "commonsense assumption", which is covertly ingrained in government policies (and, therefore, practices), has made MT education in Uganda almost unmanageable.

\section{Practical implications of findings and future directions}

In the literature reviewed in this article, it was indicated that teachers affect policy implementation. Thus, teachers can be seen as policy-makers themselves. The discussions presented in this article reveal that teachers' overt actions and practices are responses to longheld beliefs and experiences with regard to their own education practices in society.

It can therefore be argued that the challenges that appear to be impediments with regard to MT education in Uganda are a response to the colonial language policy/legacy or to political and economic structures that are inherited or that have been set up by the current government structures. The setup of the government's language-in-education policy is supported by and indicative of issues of social structure, the economy, employment opportunities, etc. Current government structures greatly undermine policies that promote MT education in communities. For example, the officialisation of English, not only in the education system but also in all government bodies, is a clear signal to the community that proficiency in this language is the key to opportunities. Accordingly, school practices are attuned to these demands. Coupled with the belief that one best acquires English when it is introduced as early as possible and that learning through a language facilitates its acquisition, the employment of MT education for only three or four years of primary schooling is viewed as unnecessary by teachers. They view MTs as an impediment to the acquisition of English and, along with parents, see MTs as subsidiary languages to English.

In conclusion, the findings of this study have revealed that there is a large gap between the language policy on paper and the language policy which is in practice in the area discussed. A future challenge could be to convince parents that being educated in MTs is not intended to deny children the opportunity to learn and become proficient in English, but that it introduces education in languages with which children are already familiar. This could facilitate the learning and possible acquisition of other languages such as English (Cummins 1980, 1981, 2000). However, if efforts to sensitise the public to the benefits of MT education prove unsuccessful, a possible solution, as argued in this paper, could come from the understanding of the linguistic ideologies within communities, and particularly in schools where language policies are central. Furthermore, there is a need for a "decolonisation" programme in Uganda as the most prominent challenges to MT education appear to be linguistic ideologies and the distribution of symbolic and material wealth, which stem from colonial education policies and seem to influence stakeholders such as teachers and parents. This type of programme may aid in ridding society of a colonial mindset and may facilitate acceptance of MT education policies. 
Finally, an education system that is to be effective should strive to challenge the colonial legacy of devaluing local languages. In other words, local languages should be positioned and feature in education and contributing to children's learning and achievement.

\section{References}

Akinnaso, F.N. 1993. Policy and experiment in mother-tongue literacy in Nigeria. International Review of Education 39(4): 255-285.

Altinyelken, H.K. 2010. Curriculum change in Uganda: Teacher perspectives on the new thematic curriculum. International Journal of Educational Development 30(2): 151-161.

Association for the Development of Education in Africa (ADEA). 2005. Learning, but in which language? ADEA Newsletter, Vol. 17 No. 2. Paris: Association for the Development of Education in Africa.

Ball, J. 2011. Enhancing learning of children from diverse language backgrounds: Mother tongue-based bilingual or multilingual education in the early years. Analytical review commissioned by the UNESCO Education Sector. France: United Nations Educational, Scientific and Cultural Organization.

Bamgbose, A. 1989. Issues for a model of language planning. Language Problems and Language Planning 13(1): 24-34.

Benson, C. 2008. Mother tongue-based education in multilingual contexts. In C. Haddad (ed.) Improving the quality of mother tongue-based literacy and learning: Case studies from Asia, Africa and South America. Bangkok, Thailand: UNESCO Asia and Pacific Regional Bureau for Education. pp. 2-11.

Cummins, J. 1980. The cross-lingual dimensions of language proficiency: Implications for bilingual education and the optimal age issue. TESOL Quarterly 14(2): 175-187.

Cummins, J. 1981. Empirical and theoretical underpinnings of bilingual education. Journal of Education 163(1): 16-29.

Cummins, J. 2000. Putting language proficiency in its place: Responding to critiques of the conversational/academic language distinction. Available online:

http://web1.tolerance.org/tdsi/sites/tolerance.org.tdsi/files/assets/general/Putting_Language P roficiency_in_Its_Place_Jim_Cummins.pdf (Accessed 18 June 2012).

Dutcher, N. 2003. Promise and perils of mother tongue education. Available online: http://www.silinternational.net/asia/ldc/plenary papers/nadine dutcher.pdf (Accessed 5 April 2012).

Fafunwa, A. B., J.I. Macauley and J.A.F. Sokoya. 1989. Education in mother tongue: The Ife primary education research project (1970-1978). Ibadan, Nigeria: University Press Limited. 
Gillham, B. 2007. Developing a questionnaire. London: Continuum International Publishing Group.

Government of Uganda. 1992. Government white paper on the implementation of the recommendations of the report of education review commission. Kampala: Uganda Printing and Publishing.

Kajubi, W.S. 1989. Education for national integration and development: Report of the education policy review commission. Kampala, Uganda: Ministry of Education.

Kateeba, C. 2009. The Thematic curriculum: Implications for mother tongue education in Uganda. Kyambogo, Uganda: National Curriculum Development Centre.

Kembo, J. 2000. Language in education and language learning in Africa. In V. Webb and Kembo-Sure (eds.) African voices: An introduction to the languages and linguistics of Africa. New York: Oxford University Press. pp. 286-311.

Kisembo, A. 2008. Thematic curriculum and local languages policy: Achievements and challenges. Paper presented by A. Kisembo at the Annual Regional Assembly on Education and Sports Sector Western Region, 16-17 October 2008. pp. 1-7. Mbarara, Uganda: Ministry of Education and Sports.

Lasebikan, E.L., R. Ismagilova and R. Hurel. 1964. Report of the study on the use of the mother tongue and the preparation of alphabets for literacy. Ibadan: UNESCO.

Marsden, P.V. and J.D. Wright (eds.) 2010. Handbook of survey research. Bingley, UK: Emerald Group Publishing Ltd.

Mouton, J. 2001. How to succeed in your Masters' and Doctoral studies: A South African guide and resource book. Pretoria: Van Schaik Publishers.

National Curriculum Development Centre. 2006a. The national primary school curriculum for Uganda, Primary 1. Kampala, Uganda: National Curriculum Development Centre.

National Curriculum Development Centre. 2006b. Primary school curriculum primary 2. Kampala, Uganda: National Curriculum Development Centre.

National Curriculum Development Centre. 2006c. Teachers' resource book (Luganda). Kampala, Uganda: National Curriculum Development Centre.

National Curriculum Development Centre. 2011. Thema: The newsletter of the thematic curriculum. Kampala: National Curriculum Development Centre.

Obanya, P. 1999. Popular fallacies on the use of African languages in education. Social Dynamics: A Journal of African Studies 25(1): 81-100. 
Read, T. and S. Enyutu. 2005. Road map for the implementation of the curriculum reforms recommended by the primary curriculum review report and approved by the Ministry of Education and Sports. Kampala: Ministry of Education and Sports.

Shohamy, E. 2006. Language policy: Hidden agendas and new approaches. New York: Routledge.

Skutnabb-Kangas, T. 2011. Why mother-tongue-based multilingual education (MLE)? MLE Newsletter 1 (Inaugural issue). Available online: http://www.tove-skutnabb-kangas.org/pdf/ Tove Skutnabb_Kangas_Why mother_tongue based_multilingual_education_MLE.pdf (Accessed 5 April 2012).

Spillane, J.P., B.J. Reiser, and T. Reimer. 2002. Policy implementation and cognition: Reframing and refocusing implementation research. Review of Educational Research 72(3): $387-431$.

Sprenger-Tasch, M. 2003. Attitudes towards Luganda, Kiswahili, English and mother tongue as media of instruction in Uganda. In H. Cuyckens, T. Berg, R. Dirven and K.-U. Panther. (eds.) Motivation in language: Studies in honour of Gunder Radden. Amsterdam: John Benjamins Publishing Company. pp. 347-366.

Ssekamwa, J.C. 2000. History and development of education in Uganda. Kampala, Uganda: Fountain Publishers Ltd.

Stroud, C. 2002. Towards a policy for bilingual education in developing countries. Stockholm: Swedish International Development Cooperation Agency.

Tembe, J. and B. Norton. 2008. Promoting local languages in Ugandan primary schools: The community as stakeholder. The Canadian Modern Language Review 65(1): 33-60.

Tollefson, J.W. 1991. Planning language, planning inequality: Language policy in the community. London and New York: Longman Inc.

Tse, S.K., M.S.K.M. Shum, W.W. Ki and C.P.C. Wong. 2001. The transition from English to mother-tongue Chinese as medium of instruction; Issues and problems as seen by Hong Kong teachers. L1-Educational Studies in Language and Literature 1: 9-36.

Uganda National Examinations Board. 2012. UCE: Exam Time Tables FINAL. Avaliable online: http://www.uneb.ac.ug/index.php?link=Timetables\&\&Key=UCE (Accessed 26 April 2013).

Unesco Regional Office for Education in Africa. 1985. African community languages and their use in literacy and education: A regional survey. Dakar: UNESCO.

Wang, H. 2008. Language policy implementation: A look at teachers' perceptions. Professional Teaching Articles 30(1): 1-38. 